\title{
Assessment on the Cash Management of Primary Cooperatives in Northern Samar, Philippines
}

\author{
Juneth Lourdes Fiel-Miranda, CPA, D.M. ${ }^{1}$, Asterio T. Miranda, Jr. Ph.D. ${ }^{2^{*}}$ \\ ${ }^{I}$ First author, Associate Professor, Keimyung Adams College ( KAC), Keimyung University, Daegu City, \\ Republic of Korea \\ ${ }^{2}$ Associate Professor, Department of Taxation, College of Business Administration, Keimyung University, Daegu \\ City, Republic of Korea \\ *Corresponding Author: Asterio T. Miranda, Jr. Ph.D. Associate Professor, Department of Taxation, \\ College of Business Administration, Keimyung University, Daegu City, Republic of Korea
}

\begin{abstract}
This study endeavored to assess the cash management of primary cooperatives in Northern Samar, Philippines whether or not they adhere to the standards for primary credit cooperatives. Specifically, it investigated the cash management practices of the registered primary credit cooperatives as regards acceleration of cash receipts and utilization of cash; determined the level of adherence to the cash management standards as regards cash planning, acceleration and utilization of cash, and cash controlling and monitoring; identified the problems that these cooperatives encountered with respect to adherence to standards for credit cooperatives; and drew recommendations from the management to solve the problems identified.
\end{abstract}

A complete enumeration of registered primary cooperatives and the management staff involved in cash management was done. Fifteen primary credit cooperatives and fifty nine management staff were qualified as the subjects and the respondents of the study, respectively.

The descriptive survey was used. A structured survey was utilized and administered directly by the researchers. The data gathered were validated through focus group discussion, observation, inspection and verification of documents. The data were treated with the use of frequencies, percentages, ranking and mean scores, and were presented using tables.

The participating cooperatives were all registered with the Cooperative Development Authority (CDA). The majority of these cooperatives lacked full-time staff and most have been in existence in the early part of the year 2000.

The cash management systems designed for credit cooperatives were partially practiced by the registered primary cooperatives in Northern Samar. December is the month when most of the cooperatives experienced high acceleration of cash receipts, while the month of March as the lowest level of cash acceleration. Two months were identified to have the highest level of cash utilization by most cooperatives namely February and June. At the same time February was also pointed out by the majority of the credit cooperatives to be their lowest level of cash utilization.

The strong points in the cash management practices of the majority of the cooperatives is the preparation of cash plans and budget. On the other hand, the weaknesses were related on the lack of full-time staff to handle the day-to-day operation, non-updating of records and individual members' ledger/passbook, and the lack of technical exposures and trainings to manage cash effectively.

The assessment revealed that the credit cooperatives in Northern Samar slightly adhered to the cash management standards for credit cooperatives, indicative of their being, less effective in their cash management systems.

The pressing problems among the majority of the primary credit cooperatives were centered on the lack of staff to handle the periodic monitoring of receipts and disbursements necessary for the preparation of cash budgets and forecasts. To solve this problem, the majority of registered primary credit cooperatives recommended for the identification and hiring of staff to handle the periodic monitoring of receipts and disbursements; as well as the establishment and maintenance of average cash balance enough for the day to day operations. This shows that the cooperatives lacked sufficient cash needed for the day-to-day operations. Although credit cooperatives partially practiced cash management systems that may be considered worthy in view of cooperative management, they had not done all those that were supposed to do to accumulate more cash. Hence, less effective cash management will result in the substandard extension of services and will ultimately cause an adverse effect on the financial solvency and viability of the credit cooperatives.

Key words: Cash management, Credit cooperatives, Cash planning, Cash acceleration and utilization, Cash controlling and Monitoring 


\section{BACKGROUND OF THE STUDY}

Cash management became an important business procedure from the time money was used as a medium of exchange. It starts when the firm render services to customers on account, and ends when the payee collect accounts payable and accrual from the firm. The activities between these two points fall within the realm of cash management.

Cash is a resource that business establishments value, and at the same time fear it. The knowledge and the actual lack of cash are of great problem to any business enterprise, since this will result in the bankruptcy or closure if it cannot be replenished. In fact, many successful, growing, promising and profitable business endeavors with good services and ready markets failed because they became technically insolvent. Even today, liquidity shortage is still one of the common reasons of many business failures.

Credit cooperatives are not exempted from the need to manage its cash in order to continuously provide credit services to the members and community. They assume a larger role in the financial markets. In fact, credit cooperatives can become effective rural development institutions and are necessary in the community, but need further development ( Tolentino, 1998). This challenge put more emphasis on the operational and financial sustainability of the credit cooperatives, and their continuity in providing financial access to the poor and to the community.

Cooperatives can sustain their operation if they have developed and strengthened their self-capacity to generate funds from member-owners; financed the main services or economic activities from the internally generated funds and managed funds effectively and efficiently. In the survey conducted by Cuarteros (1999) involving 473 cooperatives in SOCSARGEN ( South Cotabato, Sarangani and General Santos) area, it was revealed that most of the cooperatives have poor debt ratio, and the equity ratio stands at $6: 1$, and that the cooperatives have no existing financial management system nor a continuous capital build up scheme. This sad scenario reflected that large part of the assets of cooperatives in the area are financed through loans. The weaknesses of cooperatives that surfaced out in the survey by Cuarteros (1999) could also happen to cooperatives in the province of Northern Samar and could affect their levels of solvency and stability if they will not be able to efficiently and effectively manage their funds, and could cause for their dormancy.

Over the years, cooperatives in Northern Samar have been recipients of both technical and financial assistance from the non-government organizations and government agencies. Yet, based on the observations made by the researchers, some of these cooperatives are not operating well enough. Perhaps one of the causes could be the lack, if not, the absence of the continuous capital build-up programs, and the laxity on the part of the management to develop and implement internal financial plans to balance with the external source of funds, thus affecting the liquidity of the organization. In fact, the researchers also noted that only few cooperatives can come up with a cash flow statement and cash forecasts. Apparently, this area in cooperative management has not been given priority by the cooperative leaders. So far investigation along this area is minimal, hence, data that would underpin these observations are very limited, if not nil.

Along this vein, the researchers were inspired to explore the cash management practices that these registered primary credit cooperatives adopt, and find out whether they adhere to the cash management standards, and further identify the problems they encounter in the implementation of the cash management.

\section{ObJeCtives Of The Study}

The researchers endeavored to assess the cash management practices of registered primary credit cooperatives in Northern Samar to determine whether they adhere to the cash management standards for credit cooperatives. These objectives are:

1. To determine the common cash management practices of the registered primary credit cooperatives in Northern Samar as regards:

\subsection{Acceleration of cash receipts}

\subsection{Utilization of cash}

2. To determine the level of adherence to the cash management standards for credit cooperatives of the registered primary credit cooperatives in Norther Samar as regards: 


\subsection{Cash planning \\ 2.2. Cash acceleration and utilization \\ 2.3. Cash controlling and monitoring}

3. To identify the problems that the registered primary credit cooperatives in Northern Samar encountered with respect to adherence to cash management standards for credit cooperatives; and

4. To draw from the managements of the registered primary credit cooperatives in Northern Samar recommendations to solve the problems on the adherence to cash management standards for credit cooperatives

\subsection{Theoretical Framework}

Cash management is of vital importance to the success and even to the survival of every business organization. This involves various activities and implementation of techniques that will enhance the cash flow. According to Meigs and Bettner (1998) cash management refers to planning, managing cash flows and proper cash accounting. It puts more emphasis on the proper accounting and control for cash. Cash being an asset affects the basic elements in the financial statements and requires accurate accounting and control.

Keown, et. al. (1998) stressed that cash management program should include various strategies, techniques and procedures to accelerate receipts and optimize the utilization of cash and minimize cash balance which are unproductive. Moreover, it involves planning financial needs, sourcing financial needs, allocating using, and protecting funds. It requires proper matching of resources with the actual fund utilization and the need to develop and enforce the policies especially in the utilization of funds. Also, as part of the cash management program, business organizations need to establish favorable relationship with banks and other funding agencies (A. Benson and Company, n.d.)

Cash management standards were introduced by different authorities in accounting. These standards provide business firms with sound and cash management systems in order to attain their economic objectives.

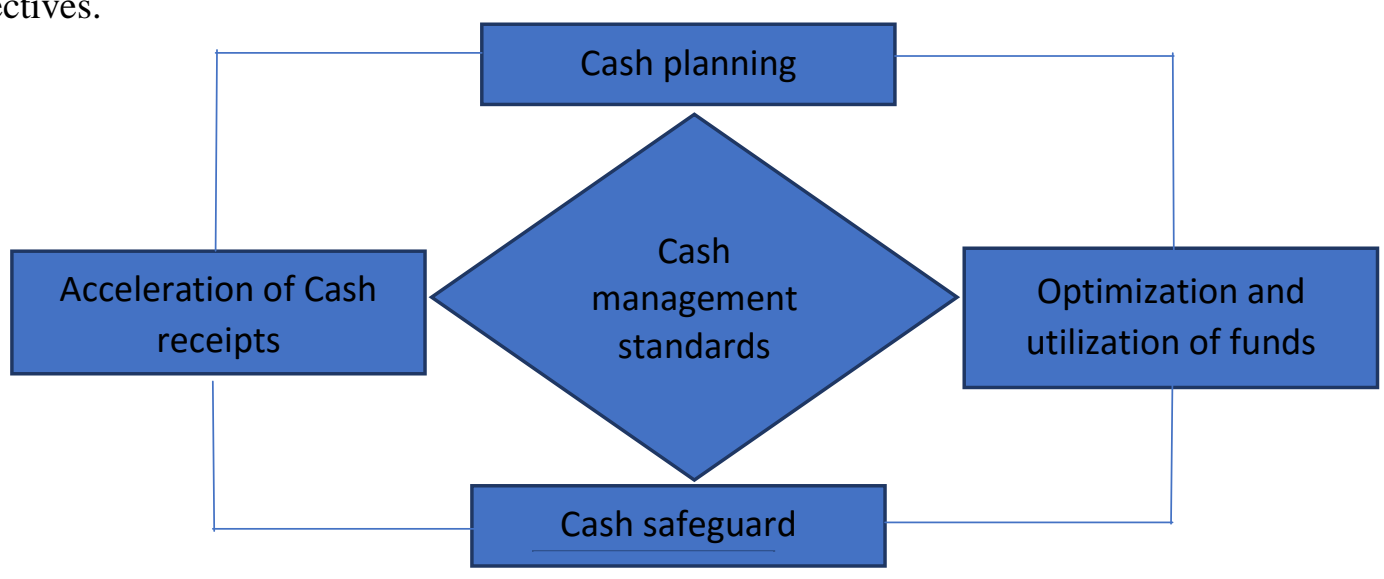

Figure1. Theoretical Framework on Cash Management

Cash planning involves anticipating the results of operation and the cooperative's future financial position and instituting remedial measures as needed (Rao,1997). Effective cash management requires an analysis of the cash flows of the cooperative which include fund utilization, and how these are financed. To guide management in formulating cash plans, review and the analysis of previous years' cash flows and the growth performance may be looked into. The current demands may help management in projecting the cash plans for the cooperative. Another tool that may assist financial managers is the cash budget. It will guide management in determining possible deviations of the anticipated path which will affect the attainment of the target. Based on the cash budget, alternative strategies may be identified to tackle possible deviations.

Another theory is the perfect synchronization of the cash receipts and disbursements. These can be achieved through the understanding of the cash flows and the use of various techniques and procedures aimed at accelerating cash receipts and improving utilization and optimization of cash (Keown, et., al, 1998). 
Safeguarding of assets, specifically cash, requires proper supervision of credit and collection, designing and implementation of accounting systems and procedures, including information systems necessary in decision making.

\subsection{Review of Literature and Studies}

\subsubsection{Cash Management}

According to Williams, et. al. (2015) cash management involves planning, controlling and accounting for cash transactions and cash balances. Because cash moves so readily between bank accounts and other financial assets, cash management really means the management of all financial resources. Efficient management of these resources is essential to the success-even to the survival of every business organization. The basic objectives of cash management are focused on providing accurate accounting for cash receipts, cash disbursements and cash balance; preventing or minimizing losses from theft or fraud; anticipating the need for borrowing and assuring the availability of adequate amounts of cash for conducting business operations; and preventing unnecessarily large amount of cash from sitting idle in bank accounts that produce no revenue.

When companies fail, one of the most common causes is their inability to manage cash. Companies must plan both cash receipts and cash payments. The goals of the cash management are two-fold: the first goal is to Plan cash receipts to meet cash payments when due, and the second is, to keep a minimum level of cash necessary to operate. To have a more effective cash management, business organizations need to adhere to the following cash management principles: a) Encourage collection of receivables, which explains that the more quickly customers and others pay the company, the more quickly that company can use the money. Some companies have cash-only sales policies. Others might offer discounts for payments received early; b) Delay payment of liabilities which emphasizes that the more delayed a company is in paying others, the more time it has to use the money. Some companies regularly wait to pay their bills until the last possible day allowed-although a company must take care not to hurt its credit standing; c) Keep only necessary levels of assets which stresses that the less money tied up in idle assets, the more money to invest in productive assets. Some companies maintain just-in-time inventory; meaning they plan inventory to be available at the same time orders are filled. Others might lease out excess warehouse space or rent equipment instead of buying it; d) Plan expenditures, which underscores that money should be spent only when it is available and companies must look at seasonal and business cycles to plan expenditures; and e) Invest excess cash indicates that excess cash earns no return and should be invested. Excess cash from seasonal cycles can be placed in a bank account or other short-term investment for income. Excess cash beyond what's needed for regular business should be invested in productive assets like factories and inventories ( Wild, et.al., 2017)

Cash management is of vital importance to the success and even to the survival of every business organization. This involves various activities and implementation of technologies that will enhance the cash flow. It needs regular monitoring of the cash flow to improve its cash efficiency of collection and likewise, be able to control disbursements. Solomon, et. al. (2000) mentioned that cash management involves a) collection and disbursement of cash efficiently, b) determination of the appropriate working cash balance, and c) investment of idle funds in order to make it productive and provide better return to investors.

Nuves (1997) averred that the goal of cash management is threefold: first, is to funnel cash into profitable operation of the business that is to provide sufficient working capital. Management should source out funds for working capital operation and the money used will result in profitable operation. Second, is to collect and conserve cash for future operation. The business firm should maintain adequate reserves that will permit the company to size opportunity and cushion against hard times. And the third is to invest idle cash to make it productive. This is to make the function for cash management self-sustaining, and should therefore generate additional profit. Ross, et al.( 1987) rejoined and stress that cash management is to plan, monitor and manage liquid resources. Cash planning requires understanding the flow-collection and utilization of funds. Regular monitoring helps management in predicting the future needs and estimation of adequate cash balance. Maintenance of cash balance will depend on the nature of the business organization. The funds generated should be planned with regard to its prioritization of utilization and maximization. 
Buchler (1983) emphasized the importance of management decisions regarding the disbursement of funds and utilization of bank services and corporate overdraft policies. Disbursements have the most significant impact on cash management program in which the policy formulation should be considered.

A. Benzon and Company et al., (n.d.) stressed that financial managers should handle the treasury and controllership function. The function of treasury involves planning financial needs; securing financial needs and maintaining favorable relations with funding agencies, private development banks, government and other agencies willing to assist the firm enhance its cash flow operations; keeping custody of funds and designing and monitoring of accounting systems with emphasis on information system. Sartories et.al. (1993) rejoined that the primary purpose of the collection system is to mobilize funds from the hands of the customers to the account of the firm. Although management must take into consideration the cost involved wherein the collection system must be balanced against the transaction costs to achieve the speed of actual collection and information generation.

Cash management according to Keown, et.al. (1998) is concerned with minimizing the business risk to insolvency. In the context of cash management, he described insolvency as the situation wherein the firm is unable to meet its maturing liabilities on time. Technically, the firm is insolvent if it lacks the necessary liquidity to make prompt payment in its current debt obligations. This can be prevented if the company has established sound cash management system. Any company can benefit from a properly designed cash management system. As sheer number of collection and payment techniques is large, but the major theme of management is controlling the cash inflows and outflows. Within the ethical confines of cash management, cash managers are always thinking of the acceleration of the firm's cash receipts and improving techniques for cash utilization and optimization of the cash saved for available cash investment program that will yield positive return. Grasping the basic elements of cash management requires understanding the underlying theories of basic financial management necessary in formulating decisions.

Management of cash requires understanding the cash flow cycle of the company. This is the central focus of cash management. The cash flow cycle represents the interval in the time lag between production process and collection and the span of time from purchasing/receiving of supplies to the payment of supplies/creditors (Horne, 1992). All activities between the two points fall under the realm of cash management. Managing cash flows includes determination of ways and techniques to accelerate cash inflows (receipts). The purpose is to mobilize funds from the hands of the customers as fast as is economically feasible. Managing collections includes the establishment of credit policy and an administration system that will ensure that cash instruments received are cleared into the cooperatives account int eh most efficient manner.

Controlling disbursement is the opposite side of collection. Effective control of disbursements can result in more availability of cash. This would simply require monitoring of payables and actual payments when the bill is due. Management should take advantage of the credit arrangements between the trading partner and the payer. The creditors usually give the payer many options in which management should not overlook but take advantage of the opportunity as long as the credit standing will not be affected. The effective control of the cooperative disbursements is an important source of cheap and convenient form of financing, but subject to the maintenance of sufficient supply of cash and goodwill of the firm. It also requires installing strong internal control and administration of payables in order to protect the funds. Only legitimate payables are actually paid by the cooperative.

Cash if not properly managed has a tendency to accumulate or be deployed in numerous pools. The continuous monitoring of the level of liquidity is required in order to reduce cost and risk to an acceptable level. The maintenance of cash balance will depend on the needs of the operation and the shareholders expectations that their investment will grow. Cash has no physical identity and is more susceptible to theft and losses. Controls should be installed to protect this asset which includes provision of business documents as official receipts for cash collections and vouchers for cash disbursements; limited persons should be responsible for cash transactions and should be bonded; authority levels must be delegated to avoid inefficiencies and proper accounting and reporting. Cash flow statements should be prepared to show the sources and uses of cash.

According to Back (1983) control of cash is essential to cash management. It requires cash position reporting. Accurate recording is necessary. Checking at all cash transactions supported by business 
documents and approval of transactions especially on cash disbursements is an integral part of the whole control system. Hence, business organizations need to formulate policies and operating procedures being an important component of the cash management system.

\subsection{Related Studies}

The study of Wijangco (1992) focused on appraising the cash management operations of seven (7) selected universities and colleges in Metro Manila.It employed the descriptive and exploratory method to research directed to determine the cash management functions, activities and techniques applicable to academic institutions. Her findings revealed that most respondents held cash for transaction needs and kept cash reserves for precautionary purpose in the form of short-term convertible investments. Cash budgeting, cash acceleration of collection through installment payment scheme of school fees and provision of incentives like discounts; safe keeping of funds; centralization of disbursement payments and bank reconciliation were among the activities in cash management. On the basis of the findings of his study, Wijangco (1992) recommended that in order to improve the management system of existing schools and universities , the following should be given consideration: 1) the need for weekly and daily preparations of cash forecast in order to generate more reliable results;2) linkage with financial establishments that will allow and provide students with credit cards for payment of school fees ; 3) to engage banks as the collection agents ; and 4) device new reporting system to reflect accurate accounting of cash position.

The study of Hameed (1992) on the "Cash Management of Selected Travel Agencies in Metro Manila: "An Analysis" focused on determining the effectiveness of the cash management practices of the fourteen (14) different travel agencies in Metro Manila, categorized as large, medium and small size. and the problems encountered by these travelagencies with regard to cash management program. His recommendations include preparations of periodic projected cash flows and forecast and improve the billing and collection systems of receivables.

In the study conducted by Almendras (1990) about the "Financial Management Practices of Entrepreneurs of Embroidered Products in Taal, Batangas" emphasized the importance of management policies relatives to the cash holding since $64 \%$ of his respondents reflected regular occurrence of deficiency in cash and working capital balance.

Sison (1989) on his study about Cash Management of Multi-National and Local Firms, focused more on the management motives in holding cash. He recommended that these firms should put more importance on the cash budget prepared daily in order to provide more reliable results. He further emphasized the need to centralize the systems on cash transactions to ensure reliability and cash controls.

The study of Datuin (1984) regarding fund management of National hospital, recommended the following: to review and design of sound internal control systems for cash with justification to prevent losses through fraud or theft; establish accountability for cash receipts and provision for adequate safegurads until the funds are placed in the hospital depository accounts; control disbursements, such that actual payment is made when vouchers were approved andlegitimate; provide sufficient amount of cash at all times in order to make payments when due; maintain adequate balance in banks; and maximize utilization of cash.

Alejandro (1992) discovered the weaknesses of some multi-purpose cooperatives on their ability to generate funds, lacking of planning and supervision, and control of cash flow. The weaknesses mentioned affected most the cooperatives' financial position, viability and growth.

Miranda (1996) conducted a study “ The Financial Accounting Systems of Registered Primary Cooperatives in Northern Samar: An Assessment " which concluded that among the problems encountered by the registered primary cooperatives in Northern Samar with regard to implementation of sound and workable accounting systems are: no full time accounting staff; lack of technical trainings in accounting; absence of qualified accounting personnel; low compensation benefits of employees; absence of cooperative accounting standards and procedures; and, weak bookkeeping systems which resulted to the absence of books of accounts, business documents, and financial statements. Few of the respondents identified utilization and sourcing of funds as one of their primary concerns. 


\section{MethodologY}

The study was conducted in the province of Northern Samar, Philippines, composed of 24 municipalities with Catarman as the capital, and the main provincial center of trade and commerce. There were 15 registered primary credit cooperatives that participated in the study, 8 or $53.40 \%$ from District 1 Central, 6 or forty percent (40\%) from Balicuatro Area; and 1 or $6.60 \%$ from Pacific Town. These cooperatives were organized and started their operation almost in the same year. All of these participating primary credit cooperatives were registered at the Cooperative Development Authority ( CDA) on the basis of the Cooperative Code of the Philippines .

The study involve fifty nine (59) respondents, 15 or $25.42 \%$ were bookkeeper/accountants, 15 or $25.42 \%$ were manager/finance officers, 15 or $25.42 \%$ were treasurer/cashier and the 14 or $23.74 \%$ were chairman/any member of the credit committee. The researchers identified the respondents based on their involvement in the adoption of cash management operations in their respective cooperative organization. The bookkeeper/accountant position had been identified since this position provide the researchers relevant information on the accounting procedures adopted by the cooperative. The treasurers/cashier or fund custodian have also been involved as part of respondents for they gave the researchers some important data on what practices their cooperative have in terms of flow of funds, while the finance officer/manager shared information on critical decisions relative to cash acceleration and utilization. Moreover, the chairman of the credit committee had also been involved as a respondent for they provide information on credit operation specifically on loan approvals and releases for which the committee is expected to closely coordinate with the treasurer or fund custodian.

The study employed the descriptive survey and utilized the following tools and techniques in gathering and validating data from the respondents:a) Interview schedule was used by the researchers in the actual interview to derive information or data on cash management practices from the identified respondents. b) Focus Group Discussion (FGD) undertaken by the researchers after conducting the actual individual interviews of the respondents. FGD was designed to bridge the possible gap or inconsistencies of information or data, which the respondents may individually provideand further enriched based on the results of the discussion specifically on the cash management practices adopted by their cooperative and whether these practices adhered to the cash management standards.

The study used the assessment interview schedule which served as a guide in the actual interview and in obtaining data. The data gathered as a result of the interview, FGD, and validation from business documents and books which the researchers have conducted, were scored and interpreted using frequency counts, percentages, ranking, and weighted means.The assessment interview schedule which the researchers used in gathering the data necessary in the study had been validated by two Certified Public Accountants (CPAs) working in existing financial intermediary and credit cooperatives in Cebu City, Philippines and are experts in cooperative accounting. The corrections and suggestions made by them have been incorporated in the final interview schedule. Moreover, the instrument was pre-tested to two (2) selected registered primary credit cooperatives in Cebu City, Philippines. The results of the pre-testing of the instrument were integrated in the final interview schedule, and used in the actual data gathering.

\subsection{Findings of the Study}

\subsubsection{Common Cash Management Practices As Regards Cash Acceleration}

The primary aim of prudent cash flow management is to make sure there will be enough cash in the coffers to meet the demands of its operation at any given time. This can be achieved by tracking the right flow patterns of cash in the business. To ensure that adequate cash is available, cash plans, budget and forecast must be prepared. The data in Table 1 indicate that the cooperatives were religious in preparing their plans and budget. All or $100 \%$ of the 15 participating cooperatives prepared cash plans and budget annually. FGD disclosed that the plans and budget were prepared by the board of directors and management staff. Although plans and budgets were done annually by the registered primary credit cooperatives in Northern Samar, only 6 or $40 \%$ conducted regular monthly evaluation.

One of the objectives in cash management is acceleration of receipts. This means reducing the delay between the time the borrowers pay their loans and the collections become usable funds for the cooperative. Several methods or techniques were introduced within the financial markets to attain the objectives and improve collection performance. The data in Table 1 reveal that 12 or $80 \%$ of the 15 
cooperatives were adopting the traditional over-the-counter method of collection technique. In fact, the data disclosed that over the counter method seemed to be the only collection technique adopted by most of these cooperatives. It may be deduced from the data that the registered primary credit cooperatives have to do a lot of updating in their collection technique in order to prove efficient services to the members for them to compete effectively within the financial markets.

Most of the cooperatives covered in the study were able to mobilize the cash receipts. Eleven or $73.30 \%$ of them adopted the monthly mode of collection, mostly in the form of currencies and coins from the member-borrower. It can be inferred from the data that cooperatives were able to recover the cash within the expected cash cycle. Collections were made in monthly installment.

In terms of the length of time spent to deposit or transfer collections to the bank, the data in Table 1 disclose that only 6 or $40 \%$ out of 15 cooperatives deposited their funds in the banks. The deposits were made in different times. One or $6.67 \%$ of cooperatives transferred their collections to the bank for deposit within twenty-four hours, 2 or $13.30 \%$ within thirty-six hours, 1 or $6.67 \%$ within sixty hours and 2 or $13.30 \%$ beyond sixty hours. This shows that the 6 or $40 \%$ cooperatives were providing adequate security measures and control over their funds. This confirms the recommendation of Wijangco (1992) for a strong linkage with financial establishments to facilitate collection and protection of funds. On the other hand, the 9 or $60 \%$ of the 15 participating cooperatives do not utilize banks for safekeeping of cooperative funds. An ocular visitation of the participating cooperatives' premises disclosed that no safety cabinets or vaults were provided by these cooperatives. The funds were being kept mostly by the treasurer. Further, it was disclosed that no banks or financial institutions were available to provide venue for safekeeping of cooperative funds. It therefore shows that the cash management of these 9 or $60 \%$ cooperatives were week in terms of control and security of cash receipts.

Recovery of cash includes provision of incentives or discounts to payee as their benefits for early payment of accounts. The study reveals that 13 or $86.70 \%$ of the participating cooperatives provide no incentive or discounts to member-borrowers. Only 2 or $13.30 \%$ among the 15 cooperatives provided incentives to member-borrowers whose loans were extinguished earlier than the maturity date in the form of awards and recognition, gift items, interest rebate on loans or cash discounts. The data indicated that the cooperatives were ineffective in cash acceleration strategy since they do not motivate borrowers to obligate their accounts earlier than the maturity date.

Control is essential in cash management. Control includes activities such as verifications, checking and validating the accuracy of amount in the cash receipts report. If possible, the control should be manualized in detail to guide new personnel in the implementation of the system. It requires documentation of transactions and the rigorous compliance by a minimum number of at least two people. The data in Table 1 reveal that eight or $53.30 \%$ maintained the cash receipts journal and cash book to record receipts transactions, only 7 or $46.70 \%$ adopted the control system of checking the accuracy of entries in the journal form the official receipts, 6 or $40 \%$ regularly checked the amount posted in the general ledger from the journal, 5 or $33.33 \%$ conducted verification of cash balance on hand, in bank and other operating funds set up with the cash ledger book, 8 or $53.30 \%$ verified the cash-on-hand balancein the ledger, and 2 or $13.30 \%$ regularly traced the accuracy of the amount reflected in the official receipts issued against the deposit slip certified by the bank. This implied that the majority of the participating cooperatives verified transactions recorded in the cash receipts journal against the official receipts issued. But it can be gleaned from the data that these cooperatives were weak in complying with the control for cash receipts since only a few conducted verification of cash balance in ledger, checked amount actually deposited with the amount receipted and the accuracy of cash balance. Technically, entries in the cash receipts journal need to be regularly checked against the official receipts to validate the accuracy of the amount reflected in the report. Since this was not apparently done, the cash acceleration performance of the cooperatives was affected. The financial reports do not provide accurate and valid information form management decision making.

In terms of the month of the year that participating cooperatives have high cash receipts collection, the study reveals that 5 or $33.36 \%$ of the participating cooperatives considered the month of December as the peak month of cash receipts, followed by the month of January as claimed by 4 or $25.67 \%$ cooperatives, next is the month of September as identified by 3 participating cooperatives. The remaining 3 cooperatives considered the month of February, July and August as their peak months. On 
the other hand, the month of March have been identified by 4 cooperatives as to the period with low cash inflow, August according to 3 cooperatives, next are the month of January, November, and December as mentioned by 2 cooperatives and the months of April and May as reported by one cooperative each.

Table1. Management Practices in Acceleration of Cash Receipts

\begin{tabular}{|c|c|c|}
\hline Management Practices & Frequency & Percent \\
\hline \multicolumn{3}{|l|}{ Preparation of Cash Plans and Budget } \\
\hline Annually & 15 & 100 \\
\hline Monthly & 0 & 0 \\
\hline \multicolumn{3}{|l|}{ Evaluation of Annual Cash Plans and Budget } \\
\hline Annual & 15 & 100 \\
\hline Monthly & 0 & 0 \\
\hline Collection techniques adopted * & Frequency & Rank \\
\hline Over the counter & 12 & 1 \\
\hline Collection services & 4 & 2 \\
\hline Payroll deduction & 2 & 3.5 \\
\hline Personalized collection & 2 & 3.5 \\
\hline Depository transfer check & 1 & 5 \\
\hline \multicolumn{3}{|l|}{ *multiple responses } \\
\hline Mode of collection & Frequency & Percent \\
\hline Monthly & 11 & 73.30 \\
\hline Weekly & 1 & 6.70 \\
\hline Every other month & 1 & 6.70 \\
\hline Quarterly & 1 & 6.70 \\
\hline Bi-monthly & 1 & 6.70 \\
\hline Length of time to transfer collection to the bank & Frequency & Percent \\
\hline Within 24 hours & 1 & 6.70 \\
\hline Beyond 24 hours but not to exceed 36 hours & 2 & 13.30 \\
\hline Beyond 36 hours but not to exceed 48 hours & 0 & \\
\hline Beyond 48 hours but not to exceed 60 hours & 1 & 6.70 \\
\hline Beyond 60 hours & 2 & 13.30 \\
\hline None & 9 & 60.00 \\
\hline $\begin{array}{l}\text { Incentive package provided to member-borrower for payment of loans } \\
\text { earlier than the maturity date }\end{array}$ & Frequency & Percent \\
\hline Interest rebates on loans & 1 & 6.70 \\
\hline Awards/recognition/gifts/prizes & 1 & 6.70 \\
\hline None & 13 & 86.60 \\
\hline $\begin{array}{l}\text { Verification, checking and validating accuracy of amount in the cash } \\
\text { receipts report* }\end{array}$ & Frequency & Rank \\
\hline Cash on hand balance is verified against the records & 8 & 1 \\
\hline The cash receipts journal are traced to the official receipts issued & 7 & 2 \\
\hline The amount posted in the general ledger is checked CRJ & 6 & 3 \\
\hline Cash balance reflected in the report is verified in the records & 5 & 4 \\
\hline The official receipts and deposit slip are traced whether recorded in cash book & 2 & 5.5 \\
\hline $\begin{array}{l}\text { The official receipts issued are checked against the deposit slip certified by the } \\
\text { bank }\end{array}$ & 2 & 5.5 \\
\hline $\begin{array}{l}\text { Surprise cash count conducted to check the validity and accuracy of the cash } \\
\text { collection } \\
\text { *multiple responses }\end{array}$ & 1 & 7 \\
\hline Month with high cash receipts collection & Frequency & Percent \\
\hline January & 4 & 26.70 \\
\hline February & 1 & 6.70 \\
\hline
\end{tabular}




\begin{tabular}{|l|l|l|}
\hline \multicolumn{2}{|l|}{} \\
\hline July & 1 & 6.70 \\
\hline August & 1 & 6.70 \\
\hline September & 3 & 20.00 \\
\hline December & 5 & 33.36 \\
\hline & & \\
\hline Months with low cash receipts collection & Frequency & Percent \\
\hline January & 2 & 13.30 \\
\hline March & 4 & 26.70 \\
\hline April & 1 & 6.70 \\
\hline May & 1 & 6.70 \\
\hline August & 1 & 20.00 \\
\hline November & 3 & 13.30 \\
\hline December & 2 & 13.30 \\
\hline
\end{tabular}

\subsection{Common Cash Management Practices As Regards Cash Utilization}

Cash utilization basically means the optimization of economic time in the settlement of obligations subject to the maintenance of an adequate supply of cash balance and credit reputation. It takes time for the cash manager to become technically familiar with a disbursement system. The more experienced cash mangers in disbursement system are, the more they can turn cash to the cooperative advantage.

The principal tools in achieving the cash disbursement objective are cash plans, budget and forecasts. These will aid cash managers in keeping an alert eye on the cash demands and avoid unexpected cash shortages. The data in Table 2 reveal that $100 \%$ or the 15 credit cooperatives prepared a disbursement plan and budget, 6 or $40 \%$ conducted annual evaluation of their plans, 4 or $26.70 \%$ conducted an evaluation of the budget monthly and 2 or $13.30 \%$ with budget evaluation annually. Likewise, the data show that the 15 participating credit cooperatives failed to prepare cash disbursement forecast. Apart from the cash plans and budget, management should take cognizance of the cash forecast as an important tool in management. Cash forecast provides management the predicted amount of cash disbursement transactions the following month or even within a week or day. Through cash forecast, the magnitude of the amount and the right timing to obligate the liability or expenditures can be accurately predicted. Without this important tool in cash management, there is a probability that the cooperative will soon lose its credibility since overdraft will be a commonplace. Ultimately, creditors will not provide credit line to accommodate future purchases, but will probably demand for payment in advance. Likewise, monitoring and modification of plans, budget and forecast must be conducted regularly. This will provide the cash managers early warnings to other areas where significant variances that will affect the achievement of the overall cooperative goals are occurring in the immediate period.

Further, the data in Table 2 reveal that not all the cooperatives observed evaluation of the actual performance with the plans, budgets and forecast. Although six or $40 \%$ of these participating cooperatives conducted an evaluation either monthly or annually, the majority or the $60 \%$ representing 9 cooperatives omitted evaluation of plans and budget as an important ingredient in cash management. Also, the respondents divulge that the variances noted by the 6 cooperatives conducting an evaluation of actual cash disbursement performance with the budget and plans were investigated. The reasons for variances were presented to the board of directors and to the general assembly. No revisions in the budget nor in the plans were made by the cooperative regardless of the materiality in the amount.

Eleven or $73.33 \%$ utilized cashbook being maintained by the treasurer, 7 or $46.70 \%$ recorded transactions in the cash disbursement journal, 6 or forty percent recorded the loan releases in the registry books maintained by the bookkeeper, and one or $6.70 \%$ utilized the loan registry book maintained by the loan officer. The data indicate that majority of these participating cooperatives maintained records for disbursement transactions. These records were mostly maintained by part-time personnel except for one participating cooperative. The interview and verification of disbursement records revealed that data entries in the record book were delayed. These weaknesses were analyzed and revealed that laxity of the officers in doing their functions also contributed to the situation.

Internal control system installed for disbursement transactions includes the verification of transaction to the working forms commonly known as disbursement vouchers and supporting documents, 
checking of proper recording from the documents to the cash disbursement book which record daily transactions; proper authorization of disbursement payments; verification of cash disbursement balance to the leger book. These disbursement controls were maintained by a minimal number of registered primary credit cooperatives. As to the internal control systems for cash disbursement transactions, the data disclosed that Seven or $46.67 \%$ of the participating cooperatives traced disbursement transactions to the cash book; 6 or $40 \%$ conduct verification of amounts reflected in the report, traced entries in the ledger to the journal, verified records in the journal to the source documents or cash vouchers and verified payments actually approved. and four or $26.67 \%$ checked the validity of payments to the actual receipts of payments by the payee; verified obligated vouchers and documents and marking on actual payment. The analyzes of the data revealed that most of these cooperatives were weak in implementing controls for cash disbursement transactions. Interview and actual verification of working forms and records provided additional information that these weaknesses in cash disbursement transactions were attributed to the laxity of officers in performing their functions. Likewise, the systems were not consistently implemented due to the status of cash management personnel mostly in part-time or voluntary service.

Various techniques and strategies were introduced in order to improve the cash disbursement management. These were tools developed to best meet the needs of the cooperatives. These disbursement techniques must be artfully blended together with the acceleration of receipts in adherence to cooperative standards. Some of the common strategies and techniques adopted by the participating credit cooperatives in the province were presented in Table 2. The data show that 11 or $73.30 \%$ of these participating cooperatives adopted centralized payments in order to control disbursements, 7 or $46.66 \%$ segregated responsibilities in the approval, signing, preparations and recording of transactions, 5 or $33.36 \%$ established and prioritized disbursements to allow timely and actual payments of cash, 4 or $26.67 \%$ controlled unused checks and vouchers, and one cooperative allowed employees to avail of loan services but accurate records on payments and balances. The data indicated that the most common cash disbursement technique is the centralization of payment. A verification of the system as adopted by the cooperatives revealed that centralized payments were not adequately complied with by the cooperatives. Proper approval of vouchers were not followed, and payments were sometimes made prior to preparations of vouchers. The analysis of the data revealed that these participating credit cooperatives were not effective and efficient in the utilization of cash.

Fifteen or $100 \%$ of the participating cooperatives utilized coin and currency in actual payment of expenditure and obligations, and 1 or $6.70 \%$ used checks and drafts. It was disclosed that 7 or $46.66 \%$ processed and released payments of loans and expenditures within 24 hours, 3 or $20 \%$ within 36 hours, 4 or $26.70 \%$ within 60 hours and 1 or $6.70 \%$ beyond 60 hours. This information revealed that in terms of disbursement transactions, most of the cooperatives took time in processing and releasing payments of loans and disbursements. The views on delayed processing and releasing payments of loans may have a positive effect on the cash management. Positive in the sense that the delay was due to the systems and control and used at the same time the allotted amount for loan releases may be utilized for investment in order to earn additional profit.

Most of the participating credit cooperatives adopted the voucher system. Eight or $53.30 \%$ installed voucher system to control disbursements. A verification of the system used by the cooperative revealed that they used the cash vouchers as their working form for disbursement transaction. The information disclosed weaknesses in cash management of most of the existing credit cooperatives in Northern Samar. Some vouchers on file do not bear the signatures of authorized persons, lacked supporting documents and receipts of payment by the payees. Except for one, these cooperatives used the basic form of payment which was the coin and currency to obligate liabilities and expenses.

The months of June and February are the period when cooperatives incurred high level of disbursement as mentioned by the 3 cooperatives in each month. April, November and December are the months identified by 2 cooperatives in each month as their highest level of disbursements. While the other 3 cooperatives mentioned January, August and September as the peak months of each cooperative. On the other hand, the period when the cooperatives experienced less payment or disbursement transactions were the months of February as claimed by 4 cooperatives, 3 cooperatives in each month claimed January and October, 2 cooperatives in each month of January, November and December and 2 cooperatives experienced low disbursement payments in the months of April and May. 
The importance of knowing the seasonal pressure and cash flow performance provides information on the cash predictability in the next period monthly or even weekly and daily. It will provide management on the right timing to seek financial assistance during lean period, and investing cash excesses. Cash flow, based on the results of FGD has never given priority attention by the primary credit cooperatives in Northern Samar

Table2. Management Practices in Cash Utilization

\begin{tabular}{|c|c|c|}
\hline Management Practices & Frequency & Percent \\
\hline \multicolumn{3}{|l|}{ Preparation of cash disbursements } \\
\hline Preparation of cash disbursement plans, budgets and forecasts & 15 & 100 \\
\hline \multicolumn{3}{|l|}{ Evaluation of actual cash disbursement payment with plans } \\
\hline Annually & 6 & 40.00 \\
\hline None & 9 & 60.00 \\
\hline \multicolumn{3}{|l|}{ Evaluation of actual cash disbursement payment with budget } \\
\hline Monthly & 4 & 26.70 \\
\hline Annually & 3 & 13.30 \\
\hline None & 9 & 60.00 \\
\hline \multicolumn{3}{|l|}{ Evaluation of actual cash disbursement payment with forecast } \\
\hline None & 15 & 100 \\
\hline Books maintained to record disbursement transactions* & Frequency & Rank \\
\hline Cashbook maintained by the treasurer & 11 & 1 \\
\hline Cash disbursement journal maintained by the bookkeeper & 7 & 2 \\
\hline Loans receivable registry book maintained by the bookkeeper & 6 & 3 \\
\hline Loans receivable registry book maintained by the loan officer & 1 & 4 \\
\hline \multicolumn{3}{|l|}{ *multiple responses } \\
\hline \multicolumn{3}{|l|}{ Activities to validate the cash disbursement* } \\
\hline Cash disbursement traced to the cash book & 7 & 1 \\
\hline The disbursement amount in the report is verified in the ledger book & 6 & 2.20 \\
\hline $\begin{array}{l}\text { The amount posted in the general ledger is checked against the check/cash } \\
\text { disbursement journal }\end{array}$ & 6 & 2.20 \\
\hline Recordings in the cash disbursement book are traced to the vouchers & 6 & 2.20 \\
\hline The disbursement report is verified against the actual documents & 6 & 2.20 \\
\hline The actual payment is based on the approved vouchers & 6 & 2.20 \\
\hline $\begin{array}{l}\text { The voucher is verified whether it was properly signed by persons authorized } \\
\text { to approve, check and receive }\end{array}$ & 4 & 8.25 \\
\hline $\begin{array}{l}\text { The voucher is marked paid and the data of actual receipt of payment is } \\
\text { reflected in the voucher }\end{array}$ & 4 & 8.25 \\
\hline $\begin{array}{l}\text { Supporting documents validated and payment checked against the perforated } \\
\text { checked returned by the bank }\end{array}$ & 4 & 8.25 \\
\hline $\begin{array}{l}\text { Loan releases are recorded in the loan registry book and posted in the } \\
\text { individual ledger } \\
\text { *multiple responses }\end{array}$ & 4 & 8.25 \\
\hline
\end{tabular}

\begin{tabular}{|l|l|l|}
\hline Strategies to control disbursements* & & \\
\hline Payment of expenditures is centralized & 11 & 1 \\
\hline $\begin{array}{l}\text { Segregation of responsibilities on approval, signing of checks, preparation and } \\
\text { recording of vouchers }\end{array}$ & 7 & 2 \\
\hline Payment of accounts established to allow litigation of bills on time & 5 & 3.5 \\
\hline Prioritize cash disbursement according to its importance & 5 & 3.5 \\
\hline Unused forms are stored in the safes with limited access to authorized persons. & 4 & 5 \\
\hline $\begin{array}{l}\text { Allowing employees avail necessary loan services and cash advances and } \\
\text { keeping accurate records of payments and balances. }\end{array}$ & 1 & 6 \\
\hline$*$ multiple responses & & \\
\hline Forms of payment used to obligate liabilities and expenditures* & & \\
\hline
\end{tabular}




\begin{tabular}{|c|c|c|}
\hline Coins and currencies & 15 & 1 \\
\hline Checks & 1 & 2.5 \\
\hline Drafts & 1 & 2.5 \\
\hline \multicolumn{3}{|l|}{ *multiple responses } \\
\hline $\begin{array}{l}\text { Length of time to process, release loans to borrowers and to be charged to } \\
\text { the coop account }\end{array}$ & Frequency & Percent \\
\hline Within 8 hours but not to exceed 24 hours & 7 & 46.67 \\
\hline Beyond24 hours but not to exceed 36 hours & 3 & 20.00 \\
\hline Beyond36 hours but not to exceed 48 hours & 0 & 0.00 \\
\hline Beyond 48 hours but not to exceed 60 hours & 4 & 26.70 \\
\hline Beyond 60 hours & 1 & 6.67 \\
\hline Disbursement techniques * & Frequency & Rank \\
\hline Voucher system & 8 & 1 \\
\hline Imprest system & 2 & 2 \\
\hline Setting up of funds for recurring transactions & 1 & 3 \\
\hline None & 6 & 4 \\
\hline \multicolumn{3}{|l|}{ *multiple responses } \\
\hline \multicolumn{3}{|l|}{ Monthly Cash Utilization } \\
\hline \multicolumn{3}{|l|}{ High Level of Monthly Cash Utilization } \\
\hline January & 1 & 6.67 \\
\hline February & 3 & 20.00 \\
\hline April & 2 & 13.34 \\
\hline June & 3 & 20.00 \\
\hline August & 1 & 6.67 \\
\hline September & 1 & 6.67 \\
\hline November & 2 & 13.34 \\
\hline December & 2 & 13.34 \\
\hline \multicolumn{3}{|l|}{ Low Level of Monthly Cash Utilization } \\
\hline January & 3 & 20.00 \\
\hline February & 4 & 26.67 \\
\hline March & 2 & 13.34 \\
\hline September & 1 & 6.67 \\
\hline October & 3 & 20.00 \\
\hline November & 1 & 6.67 \\
\hline December & 1 & 6.67 \\
\hline
\end{tabular}

\subsection{Level of Adherence to Cash Management Standards}

\subsubsection{Level of Adherence to Cash Management Standards as regards Cash Planning}

Table 3 presents the data on the level of adherence of registered primary credit cooperatives to cash planning standards. The assessment conducted resulted in weighted mean of 2.22. It indicates that cash planning as practiced by the registered primary credit cooperatives in Northern Samar was less effective. Although most of them adhere to standards of establishing a calendar for cash payment and giving priority to payment of expenditures for operations and loans, with a mean score of 2.93 reflective of effective cash management, a slight adherence was discovered on the standards where primary credit cooperatives are required to prepare, upgrade and revise both cash receipts and disbursement plans at least on a monthly basis, with similar mean score of 1.87 . This mean that the cooperatives were less effective in upgrading and coming up with revised cash receipts and disbursement plans at least on a monthly basis.

As may be deduced from the data presented in Table 3, the registered primary credit cooperatives in Northern Samar realized the importance of scheduling and prioritizing payment of expenditures for operations and loans, but they failed to take cognizance of the importance of preparing and upgrading the revising cash receipts and disbursement plans, regular evaluation of plans and budget based on actual performance at least on a monthly basis. Henceforth, the lack of cash planning affected the performance of the cooperatives. Therefore, the findings of Alejandro in his study that lack of planning, supervision and control of cash flow affected the cash management performance of an 
organization are confirmed. The claim of Hameed putting emphasis on the importance of preparing periodic cash flows in order to improve billing and collection systems, supports the validity of the above findings. The recommendation of Wijangco holds true that in order to generate reliable results of cash flow, preparation of cash budget and forecast should be done weekly and daily.

Table3. Assessment of Registered Primary Credit Cooperatives as to their Adherence to Cash Planning Standards

\begin{tabular}{|l|l|l|l|}
\hline & Indicator & Mean & Value \\
\hline 1 & Cash receipt plans are prepared, upgraded and revised at least on a monthly basis. & 1.87 & St.A \\
\hline 2 & $\begin{array}{l}\text { Formulation, implementation and regular revision or updating are conducted } \\
\text { monthly on cash disbursement plans. }\end{array}$ & 1.87 & St.A \\
\hline 3 & $\begin{array}{l}\text { Establish calendar cash payment and prioritize payment of expenditures for } \\
\text { operations and loans. } \\
\text { Weighted mean }\end{array}$ & A & $\mathbf{2 . 2 2}$ \\
\hline
\end{tabular}

Legend: $\quad$ St.A (Strongly Agree) 4 (3.26-4.00) Very effective cash management

$\begin{array}{lll}\text { A (Agree) } & 3 & (2.51-3.25) \text { Effective cash management } \\ \text { Sl.A (Slightly Agree) } & 2 & (1.76-2.50) \text { Less effective cash management } \\ \text { Nt.A (Not Agree) } & 1 & (1.00-1.75) \text { Least effective cash management }\end{array}$

\subsubsection{Level of adherence to Cash Management Standards as regards Cash Acceleration}

The data in Table 4 show the level of adherence of registered primary credit cooperatives to cash acceleration standards. As may be deduced from the data, the cash acceleration practices of the registered primary cooperatives in Northern Samar were assessed as less effective with a weighted mean of 2.25 The data further revealed that the standard of collecting loan repayment from members are in the form of cash on hand and cash items with installment of at least monthly basis. This had been strongly adhered to with a mean score of 3.40, this means that cash management is very effective as far as adopting cash management standards are concerned. The cash acceleration standards which the registered primary credit cooperatives slightly adhered to or less effective were establishing adequate internal control or safeguard, protecting cash receipts and efficient and the effective collection techniques on a sustained basis which both generated the same mean scores of 2.47. This is followed by the standards of developing, implementing and regularly updating a continuous cash mobilization program, with a 2.27 mean; formulating and implementation of collection policies which include planning, monitoring and evaluation of performance with a 2.20 mean; facilitating accreditation with bank and financing institutions for easy access of cash which derived 2.06 mean score. The other cash acceleration standards which the registered primary credit cooperatives did not adhere to, or were least effective cash management were the standard on the immediate provision of a loan amortization schedule and continuous monitoring of actual installment payment of loans by the members, having a mean of 1.67 and the standard on the formulation of collection policies which include incentive benefit packages to member-borrowers for payment of loans earlier or within the credit term, which got a mean rating of 1.53 .

As may be inferred from the data presented, the registered primary credit cooperatives seemed to be lax in the area of accelerating cash. They tend to underestimate the fact that the strength of operations of credit cooperatives is largely dependent on their capability to accelerate or mobilize more cash and ability to manage its cash liquidity more efficiently and effectively. The least effective cash acceleration standard was the formulation of collection policies for the loans extended to the members, and therefore validated the findings of Almendras that the effectiveness of cash management, if viewed in a stricter sense, rests significantly on the soundness of management policies relative to cash holding.

Internal control ensures the safety of the cooperative funds which is a factor that will motivate the members to entrust their cash to the cooperative, hence, the data indicated that the funds of the registered primary credit cooperatives in Norther Samar are not fully secured and are exposed to profitability losses. 
Table4. Assessment of Registered Primary Credit Cooperatives as to their Adherence to Cash Acceleration Standards

\begin{tabular}{|c|l|l|l|}
\hline & \multicolumn{1}{|c|}{} & Mean & Value \\
\hline 1 & $\begin{array}{l}\text { Repayment of loans from members are in the form of cash on hand and } \\
\text { cash items with installment at least on monthly basis. }\end{array}$ & 3.40 & St.A \\
monitoring of actual installment payment of loans by the members. & $\begin{array}{l}\text { Immediate provision of loan amortization schedule and continuous } \\
\text { to member-borrowers for payment of loan earlier or within the credit } \\
\text { term. }\end{array}$ & 1.67 & Nt.A \\
\hline 4 & $\begin{array}{l}\text { Adequate internal control is established to safeguard and protect cash } \\
\text { receipts. }\end{array}$ & 2.47 & Nl.A \\
\hline 5 & $\begin{array}{l}\text { Continuous cash mobilization program is developed and implemented } \\
\text { and regularly updated }\end{array}$ & 2.27 & Sl.A \\
\hline 6 & $\begin{array}{l}\text { Establish effective and efficient collection techniques in a sustained } \\
\text { basis. }\end{array}$ & 2.47 & Sl.A \\
\hline 7 & $\begin{array}{l}\text { Facilitated accreditation with bank and financing institutions for easy } \\
\text { access of cash. }\end{array}$ & 2.06 & Sl.A \\
\hline 8 & $\begin{array}{l}\text { Formulated, implemented cash collection policies which include } \\
\text { planning, monitoring and evaluation of performance. }\end{array}$ & 2.20 & Sl.A \\
\hline Weighted mean & $\mathbf{2 . 2 5}$ & Sl.A \\
\hline
\end{tabular}

Legend: $\quad$ St.A (Strongly Agree) 4

$\begin{array}{ll}\text { A (Agree) } & 3 \\ \text { Sl.A (Slightly Agree) } & 2 \\ \text { Nt.A (Not Agree) } & 1\end{array}$

(3.26-4.00) Very effective cash management

(2.51-3.25) Effective cash management

(1.76-2.50) Less effective cash management

(1.00-1.75) Least effective cash management

\subsubsection{Level of Adherence to Cash Management Standards as Regards Cash Utilization}

Table 5 presents the data on the level of adherence of registered primary credit cooperatives to cash utilization standards. The data reveal that the standard on matching properly the sources of funds with the actual utilization to maintain the minimum cash balance requirement for operations had been adhered in by the registered primary credit cooperatives, with a mean score of 2.73 . it also shows that the standards relative to the provision of loans to employees are discouraged except when necessary and for emergency cases, with a mean score of 2.47; and the adoption of management techniques to control disbursement got a 2.40 mean score which means slightly adhered to. The cooperatives were less effective in establishing a strong internal control system for cash disbursement transaction, with a mean score of 2.27; cash disbursement strategies that will enhance utilization of cash with a mean score of 2.13; the setting up of a check voucher, and imprest system with a score of 2.06 mean and the standard on the payment of bills at the earliest possible date considering discounts and other benefits for early payment which got a mean score of 2.0. Furthermore, there were standards in cash utilization which were not adhered to, making the cash management system least effective. These standards focused on the utilization of surplus cash, in excess of the operation fund requirements through temporary investments to near cash assets or cash equivalents, generating a relatively low mean score of only 1.26, and the establishment of funds for payroll dividends and other expenditures necessary for payment at specified date which derived a mean score of 1.13.

The result of the assessment along the area of cash utilization is indicative of the primary credit cooperatives' lack of strong control mechanism. It reflected their inability to manage effectively the funds of the cooperatives. This area of concern surfaced and was confirmed in the study of Datuin, who drew a recommendation that disbursements should be controlled such that payment is made only when voucher or documents are properly approved and legitimate.

Table5. Assessment of Registered Primary Credit Cooperatives as to their Adherence to Cash Utilization Standards

\begin{tabular}{|l|l|l|l|}
\hline & Indicator & Mean & Value \\
\hline 1 & $\begin{array}{l}\text { Provision of loans to employees are discouraged except when necessary } \\
\text { and for emergency cases. }\end{array}$ & 2.47 & S1.A \\
\hline
\end{tabular}




\begin{tabular}{|l|l|l|l|}
\hline 2 & $\begin{array}{l}\text { Management techniques are adopted by the credit cooperative to control } \\
\text { disbursements. }\end{array}$ & 2.40 & Sl.A \\
\hline 3 & $\begin{array}{l}\text { Strong internal control system is established for cash disbursement } \\
\text { transaction. }\end{array}$ & 2.27 & Sl.A \\
\hline 4 & Check voucher system and imprest system are set up. & 2.06 & Sl.A \\
\hline 5 & $\begin{array}{l}\text { Implementation of cash disbursement strategies that will enhance } \\
\text { utilization of cash. }\end{array}$ & 2.13 & Sl.A \\
\hline 6 & $\begin{array}{l}\text { Pauent of bills at the earliest possible date with consideration of } \\
\text { discounts and other benefits for early payment. }\end{array}$ & 2.00 & Sl.A \\
\hline 7 & $\begin{array}{l}\text { Establish payroll dividends and other expenditure funds necessary for } \\
\text { the cooperative payment at specified date. }\end{array}$ & 1.20 & A \\
\hline 8 & $\begin{array}{l}\text { Proper matching of sources of funds with the actual utilization is } \\
\text { necessary to maintain the minimum cash balance requirement for } \\
\text { operation. }\end{array}$ & 2.73 \\
\hline 9 & $\begin{array}{l}\text { Surplus cash in excess of operation fund requirements are utilized } \\
\text { through temporary investment to near cash assets or cash equivalents } \\
\text { which can be converted intro cash as need arises. }\end{array}$ & 1.26 & Sl.A \\
\hline & Weighted mean & $\mathbf{2 . 0 6}$ & Nt.A \\
\hline
\end{tabular}

Legend:

St.A (Strongly Agree) 4

A (Agree)

Sl.A (Slightly Agree) 2

Nt.A (Not Agree) 1
(3.26-4.00) Very effective cash management

(2.51-3.25) Effective cash management

(1.76-2.50) Less effective cash management

(1.00-1.75) Least effective cash management

\subsubsection{Level of Adherence to Cash Management Standards as Regards Cash Controlling and Monitoring}

Table 6 presents the data on the level of adherence to registered primary credit cooperatives to cash controlling and monitoring standards. The assessment reveals a slight adherence with the weighted mean of 2.37. And interpreted as less effective cash controlling and monitoring practice.

The standard where payment of expenditures is centralized and controlled by one department had been strongly adhered to by the registered primary credit cooperatives in Northern Samar having a mean score of 3.40. Wijangco in his study averred that an organization to be effective in its cash management practices, must adopt the system where disbursement payment and bank relations activities are centralized. Further, Sison in his study put strength on the need of a centralized system for cash transactions to ensure reliability and cash control.

The assessment further show that the adherence of registered primary credit cooperatives to the standards where the functions such as a preparation approval and recording of vouchers are adequately segregated, with a 2.86 mean score and the segregation of responsibilities among the employees handling collection and maintenance of records and those in-charge of mail receipts, having a mean score of 3.06 .

As deduced further from the data in Table 6, there were standards that were slightly adhered to, which reflect less effective cash management systems. These were collection summary report is regularly prepared, analyzed and interpreted at least on a monthly basis and all cash receipt transactions are issued with pre-numbered receipts and deposited intact in the bank the following banking day, which shared both the same mean scores of 2.40. the standards on all cash receipts transactions issued with pre-numbered official receipts, and deposited intact in the bank the following banking day, are appropriately controlled and recorded in the books of accounts with a mean score of 2.33 and 2.06 respectively. Regular monitoring of cash balance through the preparation of monthly cash position and bank reconciliation statements got a mean rating of 1.93. there were standards which were not adhered to by the registered primary credit cooperatives. Among them were checks and other cash items received are controlled, deposited in the account of the cooperatives and the actual clearing in the bank is monitored monthly, having a mean of only 1.66. The standard that all collections are deposited intact the following banking day, got 1.53 mean score. This indicates that the cash management system as adopted by the registered primary credit cooperatives in Northern Samar were least effective. 
The data likewise indicated that the registered primary credit cooperatives in Northern Samar need to improve its cash controlling and monitoring practices which most often result in problems on financial liquidity. It was evident that they adopted the centralized payment of expenditures and were controlled by only one department. There had been an adequate segregation of functions in the preparation, approval and recording of vouchers, but these are not enough at say that they have effective cash controlling and monitoring management practices.

Table6. Assessment of Registered Primary Credit Cooperatives as to their Adherence to Cash Controlling and Monitoring Standards

\begin{tabular}{|l|l|l|l|}
\hline & \multicolumn{1}{|l|}{} & Mean & Value \\
\hline 1 & $\begin{array}{l}\text { Collection summary report is regularly prepared, analyzed and interpreted at least } \\
\text { on a monthly basis. }\end{array}$ & 2.40 & Sl.A \\
\hline 2 & $\begin{array}{l}\text { All cash receipts transactions are issued with pre-numbered official receipts and } \\
\text { deposited intact in the bank the following banking day. }\end{array}$ & 2.40 & Sl.A \\
\hline 3 & $\begin{array}{l}\text { All cash receipts transactions are issued with pre-numbered official receipts and } \\
\text { deposited intact in the bank the following banking day. }\end{array}$ & 2.33 & Sl.A \\
\hline 4 & $\begin{array}{l}\text { Checks and other cash items receipted are appropriately controlled and recorded } \\
\text { in the books of accounts. }\end{array}$ & 2.06 & Sl.A \\
\hline 5 & All collections are deposited intact the following banking day. & 1.53 & Nt.A \\
\hline 6 & $\begin{array}{l}\text { Checks and other cash items received are controlled, deposited to the account of } \\
\text { the cooperative and the actual clearing in the bank are monitored monthly. }\end{array}$ & Nt.A \\
\hline 7 & $\begin{array}{l}\text { Adequate segregation of responsibilities among the employees engaged in } \\
\text { handling collections, maintenance of records and those in-charge of mail receipts. }\end{array}$ & 3.06 & $\mathrm{~A}$ \\
\hline 8 & Payment of expenditures is centralized and controlled by one department. & 3.40 & St.A \\
\hline 9 & $\begin{array}{l}\text { Adequate segregation of functions in preparation, approval and recording of } \\
\text { vouchers. }\end{array}$ & 2.86 & $\mathrm{~A}$ \\
\hline 10 & $\begin{array}{l}\text { Regular monitoring of cash balance through preparation of monthly cash position } \\
\text { and bank reconciliation statement. }\end{array}$ & 1.93 & Sl.A \\
\hline & Weighted mean & $\mathbf{2 . 3 7}$ & Sl.A \\
\hline
\end{tabular}

Legend:

St.A (Strongly Agree) 4

(3.26-4.00) Very effective cash management
A (Agree)
3
(2.51-3.25) Effective cash management
Sl.A ( Slightly Agree) 2
(1.76-2.50) Less effective cash management
Nt.A ( Not Agree) 1
(1.00-1.75) Least effective cash management

To summarize, the overall assessment as to adherence of registered primary credit cooperatives to Cash management standards as regards Cash planning, cash acceleration, cash utilization, and cash controlling and monitoring, all proved to be slightly adhered with a grand mean score of 2.22 as reflected in Table 7, and interpreted as less effective.

Table7. Summary Table of the Weighted Mean Scores on the Assessment of Level of Adherence of the Registered Primary Credit Cooperatives to Cash Management Standards

\begin{tabular}{|l|l|l|l|}
\hline Indicator & Mean & Value & Interpretation \\
\hline Cash Planning & 2.22 & Sl.A & Less Effective \\
Cash Acceleration & 2.25 & Sl.A & Less Effective \\
Cash Utilization & 2.05 & Sl.A & Less effective \\
Cash Controlling and Monitoring & 2.37 & Sl.A & Less effective \\
\hline Weighted mean & $\mathbf{2 . 2 2}$ & Sl.A & Less effective \\
\hline
\end{tabular}

Legend: $\quad$ St.A (Strongly Agree) 4

(3.26-4.00) Very effective cash management
A (Agree)
(2.51-3.25) Effective cash management
Sl.A ( Slightly Agree) 2
(1.76-2.50) Less effective cash management
Nt.A ( Not Agree) 1
(1.00-1.75) Least effective cash management

\subsection{Problems Identified by the Registered Primary Credit Cooperatives in Their Adherence to Cash Management Standards}

Table 8 presents the problems encountered by the registered primary credit cooperatives in Northern Samar relative to cash management. The reveal that the most reported problem, which ranked first, 
was the lack of a full-time staff to handle the periodic monitoring of receipts and disbursements necessary for the preparation of cash budget and forecasts. This problem also surfaced in the study of Miranda which pinpointed the absence of a full-time accounting staff which is also a priority concern of primary cooperatives. This is so because the registered primary credit cooperative in Northern Samar cannot afford to hire full-time personnel who are technically capable to handle even the basics of the cash management function. Cash management is a special field in accounting that can only be capably done by a person who has enough accounting knowledge and who is experienced in planning, implementing, monitoring and evaluating the cash flows of a cooperative.

The problems such as the lack of enough cash balance in bank and in operating funds, as well the unavailability of documents for daily cash receipts and payments shared the rank of 2.5. The former had to do with the maintenance of a cash balance in the bank and operating funds which was also revealed in the study of Datuin. About eleven (11) registered primary credit cooperatives failed to manage efficiently the liquid resources of the cooperative resulting in the inadequacy of the cash available for operation and extension of credit services to the members. While the latter, was traced to the unavailability of work forms such as official receipts, vouchers and other business forms which are being used by a cooperative in its transactions. As observed, some of the cooperatives work forms were with the persons involved in the management of cash. The treasurer kept the official receipt and the voucher were either kept by the manager or the treasurer. In effect this sometimes cause delay in some transactions.

Forecasting was one of the obstacles that impedes success in cash management, as pointed out by 8 or $53.33 \%$ of the participating cooperatives. In fact no cooperatives was able to prepare cash receipts and disbursement forecasts, much less predict the level of cash balance the following day or next week, in the next months, or years, to come. This problem was confirmed during the verification of documents.

Table8. Problems Identified to Cash Management Standards

\begin{tabular}{|l|l|l|}
\hline Problems * & $\begin{array}{l}\text { Freque } \\
\text { ncy }\end{array}$ & $\begin{array}{l}\text { Ra } \\
\text { nk }\end{array}$ \\
\hline $\begin{array}{l}\text { Lack staff to handle the periodic monitoring of receipts and disbursements necessary for the } \\
\text { preparation of cash budget and forecasts. }\end{array}$ & 14 & 1 \\
\hline Lack enough cash balance in bank and in operating funds. & 11 & 2.5 \\
\hline Documents for cash receipts and payments are not readily available on a daily basis. & 11 & 2.5 \\
\hline No established cash forecasting model to monitor its cash availability. & 8 & 4 \\
\hline $\begin{array}{l}\text { Actual cash flow as compared with forecasts and budget variances have no exploratory } \\
\text { meaning. }\end{array}$ & 4 & 5.5 \\
\hline $\begin{array}{l}\text { No identified cash available for investment and establishing investment goals and } \\
\text { guidelines. }\end{array}$ & 4 & 5.5 \\
\hline Fluctuation of cash receipts and payments are not considered in forecasting and budgeting. & 3 & 7 \\
\hline No pre-established disbursement schedule. & 2 & 8.5 \\
\hline The cooperative invests cash that usually exceeds the need for the operation of the business. & 2 & 8.5 \\
\hline *multiple responses & & \\
\hline
\end{tabular}

Other problems identified focused on the following: inability to explore the importance and meaning of comparing actual cash flow from forecasts and budget variances; no identified cash available intended for investment and establishing investment goals and guidelines; fluctuation of cash receipts and payments are not considered in forecasting and budgeting; absence of pre-established disbursement schedule; and investing cash more than the need for business operations.

The problems identified are normally encountered by the cooperatives in managing their cash. This means that cooperatives no matter how effective and efficient they are in cash management were not immune from problems, lapses or flaws in managing their cash. It goes without saying, however, that they should do something to resolve the problems when they crop up.

\section{CONCLUSION AND RECOMMENDATION}

In the context of the findings of the study, the overall assessment revealed that the majority of the credit cooperatives in Northern Samar were weak in their cash management. It was found out that the majority of them slightly adhered to the cash management standards, a manifestation of an ineffective cash management system. 
The conclusions drawn were:

1. The cash management systems designed for credit cooperatives were partially practiced and adopted by a majority of the registered primary credit cooperatives in Northern Samar in terms of cash acceleration and cash utilization.

The common cash management practices include the preparation of cash plans and budgets, evaluating performance with the plans and budget, adoption of the over-the counter collection technique, repayment or collections of loans from members by installment on a monthly and issuance of official receipts upon collection, maintaining cash book, payments is centralized and in the form of coin and currencies and voucher system in-placed.

While these cash management practices may be considered worthy in the view of the cooperative management, the cooperative failed to put into action some of the equally worthy practices. This may be the reason why most of them have not been very successful in accelerating their cash. Had they done all they were supposed to do, they would have accumulated more cash.

Financial losses from operations, of any business entity are often times caused by its inability to manage its financial resources, unwise investment decision, loss of control of disbursements and expenditures, misappropriation/juggling of funds, and other unusual events that will make the organization a financial mess. The result will ultimately bring closure to the cooperative not because of the operational losses, but due to bankruptcy.

2. The cash management practices of majority of the registered primary credit cooperatives in Northern Samar slightly adhered to the cash management standards for credit cooperatives. This resulted in less effective systems in the four major areas of cash management, namely cash planning, cash acceleration, cash utilization and cash controlling and monitoring.

Cash management standards are designed by accounting authorities based on proven successful practices which are worthy of replication in order to attain efficient and effective cash management and ensure quality control. Non-adherence to standards will result in substandard extension of service to members, massive withdrawal of unsatisfied members thus ultimately affecting financial solvency and viability.

3. The major problem affecting the majority of the registered primary credit cooperatives in Northern Samar is the lack of full-time staff to handle monitoring of receipts and disbursements necessary for the preparation of cash budget and forecast. The basics in cash management is cash planning, hence monitoring of receipts and disbursements and maintaining of average cash balance could not be done religiously by the cooperatives. The lack of technical skills, exposures and trainings of the staff handling the cash management operations also had surfaced out. The staff or manpower plays a significant role in the implementation of cash plan and budget, hence, their technical skills and knowledge in cash management need honing and upgrading. The majority of the primary credit cooperatives recommended the identification and hiring of staff who will handle the monitoring of receipts and disbursements; the establishment and maintenance of an average cash balance enough for the day-to-day operations; and the regular preparations of reports on changes in cash position which will give the management an update of the status of cash.

\section{Recommendations}

In the light of the finding that majority of the registered primary credit cooperatives in Northern Samar were weak in cash management the following recommendations were advanced by the researchers:

\section{To Primary Credit Cooperatives}

Primary credit cooperatives should redesign and install cash management systems taking into consideration the basic standards for primary credit cooperatives in order to strengthen the existing systems. The systems developed should include monitoring of cash flows such as preparation, evaluation and upgrading of cash forecast and budget at least on a monthly basis, monthly presentation of cash report, provision of incentive package, utilization of bank services for safekeeping and full utilization of funds, verification and validation of cash accuracy, maintenance of basic books of 
accounts for cash transactions, and installation of strategies and techniques to control cash disbursements and accelerate cash. Consultancy services of certified accountant may be availed by the cooperatives in the designing of the system.

Credit cooperatives whose focal operation allows the acceptance and relending of cash to its borrowers should, require the management staff to have accounting knowledge and technical skills in their fulltime capacity, who are task to handle implementation of sound cash management systems and maintenance of cash at its favorable level of liquidity to effectively handle the intricacies of cash management. Hence the hiring of at least two full-time management staff is recommended.

\section{To Credit/Financing Institutions}

Encourage financial institutions to include efficiency and effectiveness in cash management as one of the criteria used in evaluating the eligibility of the primary credit cooperatives in availing of credit services. This can be done through for a, gatherings or meetings with financial institutions/ intermediary, whether private or government providing financial assistance to credit cooperatives. This would somehow ensure that their assistance is used by the cooperatives in a manner where repayments are likely to be more favorable to both the cooperative and the financing institutions.

Furthermore, the financing institution may also develop and implement a loan package program where a component on capability and skills enhancement trainings are integrated with the credit services delivery scheme. These trainings would put emphasis on cash/fund management; internal control for cash; and other aspects of financial resource mobilization and utilization.

\section{To Development Agencies or Organizations Assisting Credit Cooperatives}

Development agencies or organizations, private or government providing technical assistance to credit cooperatives should be enlighten during cooperative gatherings to consider cash management as one potential area in the conceptualization and implementation of development programs.

\section{To the Faculty and Students of the Academic Institutions with Degree Program on Cooperatives}

A critical review of course offerings may be done during their gatherings of academic institutions implementing degree programs on cooperatives. Perhaps revisions on their syllabi or course outline specifically credit cooperatives; specialized accounting for cooperatives; management decisions for cooperatives and other related courses may be considered by emphasis on cash management.

Have cooperative students who are potential mangers, be adequately exposed and kept abreast with the different issues and concerns confronting cooperatives. This will make the students better prepared to be face eventualities in the actual management of the cooperatives, specifically credit operation.

\section{To the Cooperative Development Authority (CDA)}

The Cooperative Development Authority (CDA) and even other cooperative development institutions should include cash management as one of the indicators or criteria in the evaluation of the status of the cooperatives whether operational, developing and dormant. The cash management status be evaluated in determining cooperatives viability and operational efficiency.

\section{To the future Researchers}

A replication of this kind of study in a different research setting is recommended to further validate findings. Potential areas for research are inventories and receivable management; internal control systems; investment management and other areas must be explored and undertaken to draw out some findings that would significantly relate to what this study had empirically derived. Further inferences as to their degree of importance and interrelationships must also be established by future studies.

\section{REFERENCES}

[1] A Benzon and Company, (n.d.).Integrated Operational and Financial Management Techniques for Cooperatives (Compilation of training materials) PROCEED and CHART CO.

[2] Alejandro, Marites B.(1992) The Financial Viability of Multi-Purpose Cooperative in Isabela, An Analysis, thesis Master in Management, Isabela State University, Echague, Isabela.

[3] Almendras, Wilfredo P. (1990). Financial Management Practices of Entrepreneurs of Embroidered Products in Taal, Batangas, (unpublished) Master in Business Administration thesis, Ateneo de Manila University. 
[4] Back, Philippe L. (1983). Corporate Management., Cambridge Wood head Faulkner, 1988

[5] Buchler, Paul. ( 1983). Contemporary Cash Management Principles, Practices and Perspective, $2^{\text {nd }}$ Edition, New York: A Wiley Interscience Publication

[6] Cuarteros, Gladston A. (1999). SOCSARGEN: A Baseline Survey, Quezon City, Philippines: AngKOOP Cooperative News and Features, CFPI.

[7] Datuin, Onisonia R. (1984) Fund Management at the National mental Hospital. MBA Thesis. Ateneo de Manila University, Manila, Philippines.

[8] Hameed, Khurram. (1992). The Cash Management of /selected Travel Agencies in Metro Manila: An Analysis, (unpublished) Master in Business Administration thesis, Adamson University, Philippines.

[9] Horne, James Van C. (1992). Financial Management and Policy. New Jersey; Prentice Hall International Edition.

[10] Keown, Arthur J., Scott, David F., Martin, John D. and Petty, Jay William. (1998).Basic Financial Management, $7^{\text {th }}$ Edition, Princeton Hall, Singapore.

[11] Meigs, Robert F and Mark Betner. (1998). Accounting: The Basics for Business Decisions, $11^{\text {th }}$ Edition, Mc. Graw Hill Education.

[12] Miranda, Asterio Jr. T. (1996). The Financial Accounting Systems of Registered Primary Cooperatives in Northern Samar: An Assessment., MBA thesis, Unviersity of Eastern Philippines, Northern Samar.

[13] Nuves, Morris A. ( 1997). Operational Cash Flow Management and Control, New Jersey: Prentice Hall, Inc.

[14] Rao, Ramesh KS. (1997).Financial Management, International Thomson Publishing Co, Ohio.

[15] Ross, Derek; Clark, Allan and Taijeb, Serajul. (1987). International Treasury Management, Cambridge: Woodhead-Faulkner.

[16] Sartories, William L and Hill, Ned C. (1993). 36-Hour Cash Management Course; New York: McGraw Hill.

[17] Sison, Ricardo Jr. V. (1989) Cash Management of Multi-National and Local Firms (MBA Thesis, Ateneo de Manila University, Manila.

[18] Solomon, Sarah and Pringle, John J. (2000). An Introduction to Financial Management, Goodyear Publication Company, Inc.

[19] Tolentino, Maximo. (1998). A speech delivered during the $15^{\text {th }}$ Annual General Assembly of Quezon Federation of Cooperatives, Quezon City, Philippines.

[20] Wijangco, Leonora P.( 1992). Cash Management of Selected Universities and Colleges, (unpublished Master in Business Administration Thesis, Ateneo de Manila.

[21] Wild, John, Winston Kwok, Ken Shaw and Barbara Chiapetta (2015) Principles of Financial Accounting, Asian Global Edition 2e, Mc Graw Hill Education. Pp.322 to 326.

[22] Williams, Jay, Susan F Haka, Mark S Bettner, Joseph V Carcello, Nancy C Y Lam and Peter T Y Lau ( 2015). Financial Accounting: International Financial Reporting Standards $2^{\text {nd }}$ edition, Mc Graw-Hill Education, pp 295 to 298.

\section{AUTHORS' BIOGRAPHY}

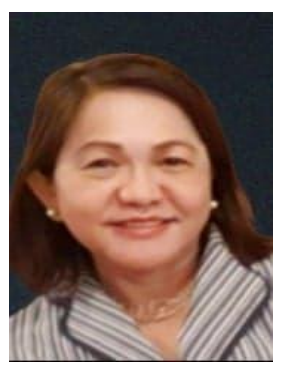

JUNETH LOURDES FIEL-MIRANDA, is an associate professor of accounting and other business related subjects at Keimyung Adams College (KAC) of the Keimyung University in South Korea. She finished her Doctorate degree in Management, major in Human Resources Management at the University of San Jose Recoletos, Cebu City, Philippines. She is a Certified Public Accountant and a member of the Philippine Institute of Certified Public Accountants ( PICPA). For over two decades, she worked as Associate Professor of accounting and other business related courses at the University of Eastern Philippines, and was involved in the development and implementation of the four-year degree program in cooperatives; and took an active role in the establishment of a collaborative linkage between the University of Eastern Philippines and the Grameen Foundation-Australia. She has been a consultant in the areas of management, systems designing and operations of the different business organizations, cooperatives and non-government organizations in the Philippines. She had published articles in a peer reviewed and refereed journals about cooperatives management, accounting systems, SMEs, human resource management and coauthored a book about research perspectives in business. 


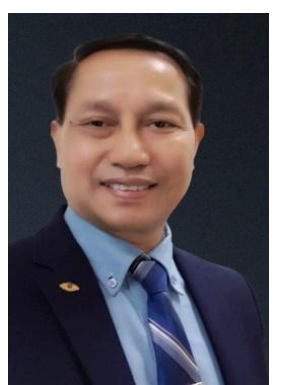

ASTERIO T. MIRANDA, JR. is a faculty member of the College of Business Administration of Keimyung University(KMU), South Korea. He Holds a doctorate degree in Extension Education, with Agribusiness Management as cognate, from the University of the Philippines at Los Banos (UPLB), Laguna, Philippines. Prior to his teaching job in KMU, he was Associate Professor of the Catholic University of Daegu, South Korea for $31 / 2$ years. Before his stint in South Korea, he was also an Associate Professor, and Chair of the Department of Agribusiness and Agricultural Economics of the College of Agriculture, Fisheries and Natural Resources, University of Eastern Philippines (UEP). He was a scholar of UEP under Plan-C of the Faculty Development Program from 1995 to 1996 while pursuing his master's degree in Business Administration at the Graduate School, UEP and for his Doctorate degree, he was awarded full scholarship by the Department of Agriculture-Bureau of Agricultural Research (DA-BAR) under the NARDSAF, from 2002 to 2004.During his teaching stint in UEP, he received Award of Distinction for Teaching Excellence for several times. From February 2008 to January, 2009 he was tapped by the World Council for Credit Union as one of its Technical Advisors of a project in Southern Afghanistan which was tasked to organize and develop Islamic Investment and Finance Cooperatives, under the auspices of USAID. He had published articles in a peer reviewed, and refereed journals about cooperatives management, non-life insurance, accounting systems, SMEs ,human resource management, tourism management, and co-authored a book about research perspectives in business.

Citation: Juneth Lourdes Fiel-Miranda, CPA, D.M., Asterio T. Miranda, Jr. Ph.D., "Assessment on the Cash Management of Primary Cooperatives in Northern Samar, Philippines" International Journal of Managerial Studies and Research (IJMSR), vol 9, no. 4, 2021, pp. 66-87. doi: https://doi.org/10.20431/2349-0349.0904007.

Copyright: () 2021 Authors. This is an open-access article distributed under the terms of the Creative Commons Attribution License, which permits unrestricted use, distribution, and reproduction in any medium, provided the original author and source are credited. 